UDC: 378.011

DOI: https://doi.org/10.24195/2414-4665-2017-4-18

\author{
Nataliia Lazarenko, \\ PhD in Pedagogy (Candidate of Sciences), associate professor, \\ rector of Vinnytsya M. Kotsiubynsky State Pedagogical University,
}

Alla Kolomiets,

PhD in Pedagogy (Doctor of Sciences), professor, vice-rector of Vinnytsya M. Kotsiubynsky State Pedagogical University,

32, Ostrozkoho Str., Vinnytsia, Ukraine,

Anatolii Klymenko,

PhD in Pedagogy (Candidate of Sciences), associate professor, Department of Practical English and Language Teaching, Ternopil Volodymyr Hnatiuk National Pedagogical University,

2, M. Kryvonosa Str., Ternopil, Ukraine

\title{
SYMBIOSIS OF METHODOLOGICAL APPROACHES TO THE DEVELOPMENT OF EDUCATION IN THE INFORMATION SOCIETY
}

One of the topical issues in modern Pedagogy is searching for and substantiating of innovative educational technologies, effective models, forms, systems of organizing educational process, methodological competency of future teachers in the information society. Such a holistic approach as symbiosis and integration of various methodological approaches (axiological, systemic, personality-oriented, cultural, synergetic, activity-based, competency-based and others) reflects the unity of nature of the investigated pedagogical phenomenon or process. However, a competencybased approach is of the highest priority among others. Its use is intended to develop a combination of young generation's competencies required for life in the modern information society, analysis and adequate evaluation of information. This approach is closely connected with other methodological approaches, highly valuable and productive in solving various educational problems. Among them the axiological approach with humanism as a leading principle is crucial. Systematized axiological knowledge can activate all other constituents of the system of values. This will make it possible to set the criteria for the evaluation of activity of institutions, old and new concepts of education, teaching experience, and also save the traditional humanistic values of domestic pedagogical theory and practice, and use them effectively in the modernization of the Ukrainian education. Synergetic and systematic approach based on interdisciplinarity contributes to the formation of creative thinking, reintegration of information on new qualitative level, understanding system connections and lead to the growth of creative potential of a person. They can be successfully used in modeling the educational environment, adaptation, in terms of didactics, of their ideas in the content of education in the management of the educational process.

Keywords: information society, education, innovative technologies, symbiosis of methodologies, competencybased approach, axiology, synergetics.

\section{Introduction}

Rapid development of the information society, being one of the principal objective factors to intensify integration processes into international educational space, reform the education system, search for effective models, forms, and systems of organization of the educational process, determine the need for sufficiently trained, practically oriented specialists, able to think both theoretically and creatively, as well as capable of reifying plans taking into account the problems of our society (Kushnir, 2003).

The most radical changes in the society, including revolutionary transformations in Ukraine set complex tasks for the national education.

Scientists are increasingly paying attention to a special role of a teacher in the new environment of intensification of integration processes in the international educational space, the development of information society, which requires his/her creative personality, willingness to work at a new school, able to design, develop and use innovative projects.

Based on the above mentioned, the aim of this paper is to investigate the most effective methodological approaches, models, forms and systems of organizing professional pedagogical education, the formation of future teacher's methodological competency, ensuring his/her ability to organize a highly qualified educational process, research, master the innovative learning technologies and information systems, generalize advanced pedagogical and methodological experience, critically evaluate the results of his/her activities, work on selfimprovement.

Discussion

Methodological competency, one of the components of professional competency of a modern teacher, is defined as the ability to see problems in the educational process, find ways of their solution, and prove the correctness of his/her decision, use adequate methodological 
approaches in the process of solving theoretical and practical tasks, compare and evaluate the concepts of different teachers and researchers, experience of other teachersinnovators.

Being one of the most complex components of future teacher's professional training, methodological competency appears to be the least investigated aspect of professional training in scientific literature.

Since the main task of a teacher is the formation of a competent, multicultural, comprehensively developed, spiritually rich, perfect personality, it is a symbiosis of various methodological approaches which must be a methodological basis of the concept of education.

The complex of ideas, theories and approaches which are selected to be the methodological principles of improving the quality of education is the "prism" through which and due to which, the essence of the object of study is brought to light, its ideas are modeled, the search for the means and conditions for improvement, effective development is made. According to Ukrainian academician I. Ziaziun, methodological principle of integrity, the so-called holistic integrated approach, which researchers often refer to as the methodological basis of research, is important in terms of specificity of pedagogy as humanitarian and active in progress science (Ziaziun, 2011). We believe that the holistic approach integrating different methodological approaches in fact displays integrated nature of the investigated pedagogical phenomenon or process.

The use of such methodological approaches as axiological, systemic, personality-oriented, cultural, synergetic, activity-based, competency-based and others in pedagogy has reached certain success (Kolomiiets, 2016, p. 48). However, it is the competency-based approach that educators have recently preferred. Its use is intended to develop a combination of young generation's competencies required for life in the modern information society. It is closely connected with other methodological approaches, highly valuable and productive in solving various educational problems, and primarily in overcoming dehumanization of education, when neither secondary nor higher education transmitted human and national culture (Ziaziun, 2011).

Therefore, we consider it appropriate to apply a complex of methodological approaches in education, which will be characterized hereinafter.

Pedagogical axiology can be defined as a special area of pedagogical knowledge, where upbringing, education, learning, and pedagogical activity are regarded as values of human life (Ginecinskii, 1992, p.75). It treats educational values from the position of human selfesteem, and provides value approaches to education itself based on recognition of value of education (Slastenin \& Chizhakova, 2003, p.99).

The essence of axiological approach, which defines a man as the highest goal of social development, and educational process - as expanded reproduction of social and cultural experience, lies in focus of teaching individ- ual's humanistic development as a target, subject, result and the main criterion of its effectiveness. It is one of the leading approaches in the context of humanistic pedagogy and psychology, since it recognizes every participant of the educational process as active value-motivated subject of activity, and allows to build subject-subject relationships, and create a favorable psychological climate.

It also serves as a bond between cognitive and practical attitude to the world (theory and practice), since the content of evaluative, target, and activity aspects of human life is determined by focus of individual's activity on reflection, recognition, updating and creating material and spiritual values.

Thus, the axiological approach, which is naturally inherent to humanistic pedagogy, is extremely important in education, since it makes it possible to consider personally meaningful and vital human needs, selfdevelopment of the participants of the educational process as an educational value, focuses on identification of various linkages of personal fulfillment.

The idea of humanization aims to implement a fundamentally different orientation of education to prepare for achieving overall efficiency, professional and personal development. According to M. Boryshevskyi, when it comes to the transformation of the value system or its radical restructuring, a focus should be made on keeping to such principles as pluralism, alternative, humanoriented, since these are the very principles providing the possibility of values system formation, which opens space for personal development of a creative and free individual, capable of independent and responsible choice (Boryshevskyi, 1997, p.144-150).

Thus, the principle of humanism is leading for the development of future specialists' communicative competency, since it has to be a basis for communicative interaction among all participants of the educational process, including administration, students, teachers, foreign colleagues and others.

The implementation of anthropological approach into education is associated with philosophical thought and various kinds of management anthropology (R. Descartes, J. Herder, I. Kant, L. Feuerbach). Modern psychological and pedagogical concept of higher education, developed by V. Bekhteriev, P. Lesgaft, A. Nechayev, implemented it into the formation of a creative personality of a teacher-researcher. Freedom of teaching and learning is a systemically-developing anthropological principle of higher education: a student becomes independent in the choice of subjects and methodology for defining methods, timing and means of study. Anthropocentric conception of education is based on the principle of freedom of choice of learning on condition that students are independent in educational planning.

In the $21^{\text {st }}$ century, the operation of humanistic education and educational systems is impossible without the focus on educational support aimed at the formation and development of a student as an author and creator of 
his/her destiny, as a personality with many characteristics significant for the society. Thus, the student-centered approach is required. It primarily changes the goal of the educational process, aiming to form and develop student's personality characteristics.

Since a personality is a rather complex system of qualities and characteristics, there has appeared a need for the development of methodology and technology of implementation of the systemic and the activity-based approaches in education.

The systemic approach is generally treated by scientists as the methodological direction, developing means of study and design of sophisticated and complicated subjects. The systemic approach is a methodological tool to study integration, integrated facilities, relationships and interactions. As a methodological tool in the ontological and epistemological aspects it involves the creation of a unified object model as a whole, which serves as a means of organizing research of the educational process. The research related to the study of system and structure of its connections, operation and development, management, is a system, only on condition that it is complied with basic methodological principle of the system integrity.

The systemic approach also focuses on the analysis of the components, which form the phenomenon under study, the relationship between them - the structure of the educational system, its functions as a product of a particular structure and characteristics. The efficacy of the systemic approach is defined by how integral (full, hierarchical, structured) is understanding of these characteristics of the system, their features, generated by the interaction of components.

The systemic approach to the objects under study involves consideration of the object of study as a system, identifying certain number of its elements, creating, classification and regulation of relations between these elements, defining system forming connections, which provide integration into a system; considering external influence of the system of a higher hierarchy and internal interference of subsystems.

The systemic approach is closely connected with the synergetic approach. Unlike the systemic approach, which is focused on connections of parts in unity, synergetics is a new generalizing science that studies the basic laws of self-organizing complex systems. It includes areas such as nonlinear dynamics, chaos, fractals, catastrophe, bifurcation, waves, field effects, etc., which once originated in physics and chemistry.

Popularity of synergetics, which has rapidly increased lately, may be explained by the fact, that it has become a language of interdisciplinary communication, meta-science, which can be understood by physicists, mathematicians, linguists, psychologists and others, despite the fact that everyone understands the synergetic model in their own way.

Based on the effect of strengthening actions in education resulting from the use of study information through various channels of perception, synergetic approach re- quires recourse to the selection of methodological tools considering specificity of subject knowledge. Synergetics, as the effect of increasing the efficacy of learning through relationship and inter-strengthening of various actions in training, can be realized through the use of logical and imaginative, abstract and visual, qualitative and quantitative means in their inter-transitions in education. This is due to nonlinear thinking, which accommodates selection, correction and evaluation. Non-linear thinking processes in training are most clearly manifested when solving complex problems. The role and function of tasks of the increased complexity in teaching are considered to be great. They are the means of understanding the phenomena and laws, and allow a student to understand complicated inter-relationship between qualitative and quantitative parties of the objects of knowledge.

Synergetics, as an attempt to build new deep interdisciplinary approaches, reveals a new image of the world of nature, a human and society as open dynamic systems, which are developed by nonlinear laws, and substantiates the dual nature of random. Synergetic approach gives an opportunity to view human evolution considering its integrity. Analyzing the phenomenon of "spirituality", T. Tyurina has come to the conclusion that synergetic pedagogy provides new opportunities and perspectives for understanding the nature of spirituality, evolutionary processes occurring in the holistic nature of a human being (Tiurina, 2009, p.149).

Thus, methodological settings of synergetics fundamentally change the traditional understanding of the cognitive process, treating it as a body capable of selfadjustment and finding new alternative ways of development. The specificity of the methodology of interdisciplinary knowledge lies in the paramount importance of integrative synthesizing trends.

Integrated study of related material, strengthening the influence of various analyzers in the perception of information, combining various sources of information, given in different forms, provide strong synergetic effect. Educational space and human activity, their selfdevelopment are a complex object rather than a clearly built and managed system. In its evolution they comply with complex and little-known laws of functioning and self-development of complex synergetic systems. Therefore, the synergetic approach becomes important, since it puts forward such features of complex systems as their certain chaotic nature, and at the same time, the ability for self-development.

It is important to consider the interaction mechanisms of local systems with meta-systems, which is extremely necessary for the educational systems, integrated into all positive and negative processes of civil, economic and cultural development of the society and an individual in particular.

Synergetic approach also encourages us to review the main structural components of the educational process: content, methods of education and training, taking into account the integrity of a person. The scientists have 
found out that the more complete and integrated our understanding of factors affecting the achievement of the objectives of educational systems is, the more structured these ideas are which involves, in particular, knowledge about the dominant factors in a certain situation, operation and development, the more effective the synergetic approach will be (Ziaziun, 2011, p. 8).

Psychologists persuasively proved that knowledge is best acquired in the process of activity. Therefore, the activity-based approach is nowadays widely used in education. Including its characteristics into goals and objectives of the educational process, it mainly rebuilds its procedural and technological side in the way, so that students master activity in an integrated manner (Ziaziun, 2011, p.8).

Training in terms of certain culture and its mandatory interaction with other cultures, requires entering and mastering it. The educational process is always influenced by the mentality of a country or region, where it takes place, and where a student is from.

The development of value orientations during professional training should be carried out in three main directions: forming axiological attitude of students to the profession, creating a student's professional image 'I am a teacher". Accordingly, students should have a system of professional value orientations formed, which determine the attitude of an individual to the peculiarities of profession, reflect the content side, the basis of professional activity, its objectives. That is why the cultural approach is necessary, its methodology, corresponding regulations to solve all educational tasks. The cultural approach, and its methodology are particularly significant since they define the key regulations of building educational content, including representation requirements, reflection of major achievements of the human mind and human activities, the richness of human cultures, their relationships and interactions. These views should be systemic, complete, necessary and sufficient for the successful entry of the subject of education into the world of culture in all its manifestations - the scientific field, social production, daily life, self-development, etc., its mastering and, if possible, development.

Positions of the cultural approach extend the limits of traditional training, firstly, not only through activation of sensory perception of the world, but also reproduction of a cultural dialectics of the process of cognition of the world. Secondly, outlook of cultural education determines the need to include not only spiritual forms of human activity, but also knowledge of nature, technologies of objective environment, products of socio-economic development of the society from general cultural perspective.

Dissemination of information and communication technologies has considerably enhanced opportunities for information search, as well as for analysis and adequate evaluation and use of information. Therefore, we consider it appropriate to use the information approach in education.

The impact of information and communication technologies on organizational forms, methods and learning outcomes are intensively studied by scientists (V. Bykov,
R. Gurevych, M. Zhaldak, N. Morze et al.). Priority in the research belongs to the development of software for computer-oriented systems and technologies, textbooks and training materials in electronic form.

Implementation of information and communication technologies into education should result in improving the quality of education at all levels through the advent of automated systems for mass dissemination of information, publishing educational literature in the electronic form, introduction of methods, software and hardware required for distance learning.

The use of information and communication technologies includes updates in teaching methods, using problem, heuristic, game and other forms of teaching, increasing the possibility of learning tasks individualization. In this case, means of communication, combining lectures and workshops contribute to the creation of new educational ideas, which can be used alone or in the process of integration of study courses.

Based on the fact that the challenges which humanity faces are global, they should be solved also globally. It is therefore advisable in solving the problems of education in the information society to use globalization approach, which takes into account that in terms of informatization and the intensification of international and interstate economic, scientific and cultural ties, there is a constant comparison of different types of cultures and worldview, their interpenetration and interaction.

Openness regarding other cultures is a condition for enrichment and development of any national culture, condition for cultural development of each personality. With the development of the information society, the role and significance of individuality, their interest in global issues on the basis of common values considerably increases (Solianyk, 2002, p. 70).

We agree with O. Robul's statement that educational activity in the information society should be aimed at the upbringing of a modern personality, a subject of the world civilization, having universal characteristics, noosphere thinking, the planetary consciousness, multiculturalism, humanistic culture, citizenship, tolerance, etc. (Robul, 2006, p. 37).

\section{Conclusions}

The above mentioned allows us to make the following conclusions:

- Education in the information society must ensure Ukraine's integration into the European economic, cultural, and educational structures. This requires scientific and theoretical substantiation of the most relevant methodological approaches, and their use as a complex in the development of the system of education of Ukraine.

- An integration of methodological approaches is needed. This will ensure the development of a universal mechanism for designing the content of training at higher educational institutions. This mechanism, working proactively, will make it possible to educate a personality to be in harmony with himself/herself, the environment, and 
capable of solving professional tasks of future teaching activity on a higher level.

- In the process of the development of education the following methodological approaches are of the high-

\section{REFERENCES}

1. Boryshevskyi, M. Y. (1997). Dukhovni tsinnosti v stanovlenni osobystosti y hromadianyna. [Spiritual values in the development of an individual and citizen] Pedahohika i psykholohiia - Pedagogy and psychology, 1, 144-150 [in Ukrainian].

2. Ginetsinskiy, V. I. (1992). Osnovy teoreticheskoy pedagogiki. [Fundamentals of theoretical pedagogy]. Saint Petersburg: izd. S-Peterb. un-ta [in Russian].

3. Ziaziun, I. A. (2011). Tsilisnyi metodolohichnyi pidkhid $\mathrm{u}$ pedahohichnomu naukovomu doslidzhenni [Holistic methodological approach in pedagogical scientific research]. Proceedings of the $4^{\text {th }}$ International Theoretical and Practical Conference "Professional development of a personality: problems and perspectives”, (pp.713). Khmelnytskyi [in Ukrainian].

4. Kushnir, V. A. (2003). Teoretykometodolohichni osnovy systemnoho analizu pedahohichnoho protsesu vyshchoi shkoly [Theoretical and methodological basis of the system analysis of educational process at a higher educational instritution]. Extended abstract of doctoral thesis. Kyiv [in Ukrainian].

\section{ЛІТЕРАТУРА}

1. Боришевський М. Й. Духовні цінності в становленні особистості й громадянина / М. Й. Боришевський // Педагогіка і психологія. - 1997. - №1. - С. 144-150.

2. Гинецинский В. И. Основы теоретической педагогики. / В. И. Гинецинский. - СПБ: изд. СПетерб. ун-та. - 1992. - 154 с.

3. Зязюн І. А. Цілісний методологічний підхід у педагогічному науковому дослідженні / Іван Зязюн // Професійнестановлення особистості: проблеми і перспективи: Матеріали IV міжнародної науковопрактичної конференції. - Хмельницький: 2011. C.7-13.

4. Кушнір В. А. Теоретико-методологічні основи системного аналізу педагогічного процесу вищої школи: Автореф. дис. д-ра пед. наук: 13.00.04 / В. А. Кушнір // Ін-т педагогіки і психології проф. освіти АПН України. - К. - 2003. - 39 с. est priority: systemic, synergetic, axiological, anthropological, student-centered, activity-based, competencybased, cultural, information and globalization.

5. Robul, O. (2006). Synerhetyka yak innovatsiina metodolohiia pedahohichnoi osvity. [Synergetics as innovative methodology of pedagogical education]. Filosofiia osvity - Philosophy of education, 1(3), 35-42 [in Ukrainian].

6. Slastenin, V. A. \& Chizhakova, G. I. (2003). Vvedenie v pedagogicheskuju aksiologiju [Introduction to pedagogical axiology]. Moscow: Akademiya [in Russian].

7. Solianyk, S. F. (2002). Demasyfikatsiia kultury na zlami tysiacholit. [Demassification of culture at the turn of the millennium]. Naukovi zapysky KITEP: Shchorichnyk - Scientific notes: annual journal, 2, 64-72 [in Ukrainian].

8. Tiurina, T. H. (2009). Pedahohika dukhovnosti: synerhetychnyi pidkhid. [Pedagogy of spirituality]. Dukhovnist osobystosti: metodolohiia, teoriia i praktyka: $z$. nauk. pr. - Spirituality of a personality: methodology, theory and practice: collection of scientific works, 30, 144-162 [in Ukrainian].

9. Haken, G. (1980). Sinergetika [Synergetics]. Transl. Moscow [in Russian].

5. Робуль О. Синергетикаяк інноваційна методологія педагогічної освіти / О. Робуль // Філософія освіти. - 2006. - № 1(3). - С. 35-42

6. Сластенин В. А. Введение в педагогическую аксиологию. // В. А. Сластенин, Г. И. Чижакова. - М.: Академия. - 2003. - 192 с.

7. Соляник С. Ф. Демасифікація культури на зламі тисячоліть / С. Ф. Соляник // Наукові записки КІТЕП: Щорічник. - К.: Знання України, 2002. Вип. 2. - С. 64-72.

8. Тюріна Т. Г. Педагогіка духовності: синергетичний підхід / Т. Г. Тюріна // Духовність особистості: методологія, теорія і практика: зб. наук. пр. / Гол. ред. Г. П. Шевченко. - Вип. 30. - Луганськ: Вид-во Східноукр. нац. ун-туім. В. Даля, 2009. - С. 144-162.

9. Хакен Г. Синергетика: пер. с англ / Г. Хакен. - Москва, 1980. - 406 с. 
Наталія Іванівна Лазаренко, кандидат педагогічних наук, дочент, ректор Вінницького державного педагогічного університету ім. М. Коцюбинського, вул. Острозького, 32, м. Вінниця, Украӥна,

Алла Миколаӥвна Коломієць, доктор педагогічних наук, професор, проректор з наукової роботи, Вінницький державний педагогічний університет ім. М. Коцюбинського, вул. Острозького, 32, м. Вінниия, Україна,

Анатолій Олегович Клименко, кандидат педагогічних наук, дочент кафедри практики англійської мови та методики ї̈ викладання, Тернопільський національний педагогічний університет імені Володимира Гнатюка, вул. М. Кривоноса, 2, м. Тернопіль, Украйна

\section{СИМБІОЗ МЕТОДОЛОГІЧНИХ ПІДХОДІВ ДО РОЗВИТКУ ОСВІТИ В УМОВАХ ІНФОРМАЦІЙНОГО СУСПІЛЬСТВА}

До актуальних проблем сьогодення, які ще недостатньо розроблені у науковій літературі, належить пошук й наукове обгрунтування інноваційних педагогічних технологій, ефективних моделей, форм, систем організації навчального процесу, методологічної компетентності майбутнього педагога в умовах інформаційного суспільства. Мета статті - дослідити найбільш ефективні підходи, моделі, форми й системи організації професійної педагогічної освіти, формування в майбутнього педагога методологічної компетентності, котра забезпечує його здатність на високому рівні організовувати освітній процес, здійснювати наукові дослідження, опановувати інноваційні технології навчання та інформаційні системи, узагальнювати передовий педагогічний і методичний досвід, критично оцінювати результати своєї роботи, творчо працювати над самовдосконаленням. Доведено, що цілісний підхід як симбіоз й інтеграція різноманітних методологічних підходів (аксіологічного, системного, особистісного, культурологічного, синергетичного, діяльнісного, компетентісного й інших) здатен відображати цілісну природу досліджуваного педагогічного явища чи процесу. Перевага надається компетентнісному підходові, застосування якого покликане сформувати в молодого покоління сукупність компетентностей, необхідних для здійснення життєдіяльності в сучасному інформаційному суспільстві, аналізу й адекватного оцінювання та використання інформації. Педагогічна діяльність в умовах інформаційного суспільства має бути спрямована на виховання інноваційної людини - суб'єкта світової цивілізації, універсальними характеристиками якого $є$ глобальне мислення, планетарна свідомість, полікультурність, гуманістична культура, громадянськість, толерантність, здатність до життєтворчості в глобальному масштабі. 3 компетентнісним підходом органічно пов'язані й інші методологічні підходи, які також надзвичайно цінні й продуктивні у вирішенні багатьох педагогічних проблем. Серед них найбільш важливим $\epsilon$ аксіологічний підхід, в основі якого провідним $\epsilon$ принцип гуманізму. Систематизовані аксіологічні знання здатні активізувати всі інші ланки системи цінностей, що дозволить встановити критерії оцінки діяльності установ, старих і нових концепцій освіти, педагогічного досвіду, а також зберегти традиційні гуманістичні цінності вітчизняної педагогічної теорії і практики та ефективно використовувати їх у модернізації української освіти. Методологічні установки синергетики - нової універсальної парадигми, що використовується для вирішення педагогічних проблем, які не піддаються розв'язанню класичними методами, - кардинально змінюють традиційні уявлення про пізнавальний процес, трактуючи його як організм, здатний до самокоригування і пошуку нових альтернативних шляхів розвитку. Синергетичний й системний підходи, які базуються на міждисциплінарності, сприяють формуванню творчого мислення, реінтеграції інформації на новому якісному рівні з розумінням системних зв'язків й ведуть до приросту креативного потенціалу особистості. Вони можуть успішно застосовуватися в моделюванні і прогнозуванні освітнього середовища, адаптації з погляду дидактики їх ідей в змісті освіті, в управлінні навчальновиховним процесом.

Ключові слова: інформаційне суспільство, освіта, інноваційні технології, симбіоз методологій, компетентнісний підхід, аксіологія, синергетика.

Submitted on March, 28, 2017 